\title{
ETABLERINGEN AV EN
}

\section{INTERNATIONELL BROTTMÅLSDOMSTOL}

\section{Domstolen, dess jurisdiktion och domstolsförfarandet}

\author{
Av P. O. TRÄSKMAN
}

\section{1. "THE HISTORIC WORLD CONFERENCE"}

I december 1992 arrangerades i Syracusa på Sicilien en konferens för att behandla etablerandet av en internationell brottmålsdomstol. Det brev som innehöll en inbjudan till konferensen började:

On behalf of the prestigious co-sponsoring organizations listed in the Draft Program attached, I have the privilege and pleasure to invite you to attend this historic World Conference which will gather world leaders, distinguished parliamentarians, and leading academics on the establishment of an International Criminal Tribunal.

I brevet beskrevs därefter tidigare planer på och försök att grunda en internationell brottmålsdomstol med kompetens att döma personer som gjort sig skyldiga till krigsbrott, brott mot freden, brott mot mänskligheten och andra internationella brott. Med hänvisning till den ökning av "den gränsöverskridande brottsligheten" som ägt rum efter det andra världskriget och de nationella straffrättssystemens oförmåga att effektivt lagföra personer som gjort sig skyldiga till sådana brott, fastslås därefter att tiden nu är mogen för att grunda en internationell brottmålsdomstol. Detta framställs som ett nödvändigt steg för att befrämja "the international rule of law and a new world order based on equal justice and the protection of individual and collective human rights". 1

Bakgrunden till det aktuella initiativet att grunda en internationell brottmålsdomstol och domstolens tänkta sammansättning, behörighet, uppgifter och verksamhet beskrivs utförligare i en publikation skriven av professor $M$. Cherif Bassiouni, Draft Statute International Criminal Tribunal. ${ }^{2}$ Som titeln anger innehåller denna publikation ett förslag till grundstadga för en internationell brottmålsdomstol. Trots att detta förslag till grundstadga inte i egentlig mening behandlades vid "den historiska konferensen" på Sicilien, var det uppenbart att konferensen sammankallats just för att rekommendera att en internationell brottmålsdomstol skall inrättas och att detta sker med stöd av och i enlighet med den grundstadga som föreslagits av Bassiouni. ${ }^{3}$

Jag antar att också andra än jag spontant reagerar i grunden positivt - men samtidigt skeptiskt - på förslaget att inrätta en internationell brottmålsdomstol. Vid en tidpunkt då det inte är nödvändigt att söka sig till historiebökerna för att finna beskrivningar på grymheter i krig, utan dessa finns i överflöd i dagsnyhe- 
terna t.o.m. från länder i vår egen världsdel, är det lätt att ställa sig positiv till ett vart förslag som kunde innebära effektiva åtgärder för att förhindra våldsgärningar som leder till hundratusentals människors död. Om en internationell brottmålsdomstol faktiskt kan bidra till en sådan ny rättvis världsordning som innebär att alla människor kan leva i fred och välmåga, kan den konferens vid vilken det avgörande beslutet om att inrätta domstolen fattas med rätta kallas för "historisk".

En sådan tro på de möjligheter som en internationell brottmålsdomstol erbjuder har numera också manifesterats i det principbeslut som FN:s säkerhetsråd fattade 22.2.1993 om att en krigsförbrytardomstol skall inrättas för att döma dem som anses ansvara för krigshandlingarna i det tidigare Jugoslavien.

Skepticismen mot förslaget att etablera en internationell brottmålsdomstol underbyggs åter i första hand av vetskapen om att alla tidigare försök att grunda en internationell brottmålsdomstol har gått om intet på grund av starkt politiskt motstånd, bl.a. från de stora världsmakternas sida. ${ }^{4}$ Då en stat avstår från sin egen rätt att lagföra brottslingar och överlåter den åt ett internationell domstol, vars jurisdiktion är exklusiv och vars domar är slutliga och bindande, inskränker den sin egen suveränitet på ett väsentligt sätt. Särskilt för en mäktig stat är detta ett politiskt svårt beslut. ${ }^{5}$

Tveksamheten mot förslaget kan också grundas på misstanken om att domstolen inte kommer att få en sådan makt som krävs för att det internationella straffrättssystem som byggs upp kring den blir effektivt. Vad finns det för garantier för att en person som har begått ett sådant internationellt brott som domstolen skall handlägga verkligen blir ställd till ansvar inför domstolen? ${ }^{6}$ Och hur skall sedan de straff som möjligen utdöms blir verkställda?

Men tänk om förslaget att grunda en internationell brottmålsdomstol faktiskt realiseras och dess verksamhet och betydelse blir sådan att den ställer alla misstanker om ineffektivitet på trots. Har man då faktiskt lyckats utveckla rätten och rättssystemet i en positiv riktning? Det man i så fall har gjort är ju i själva verket att man byggt ut och förstärkt det straffrättsliga systemet, d.v.s. ökat den straffrättsliga repressionen på ett universellt plan.

Att använda straff mot människor är alltid en verksamhet som måste kunna rättfärdiggöras med godtagbara argument. Under de senaste decennierna har användningen av straff som ett medel för att styra människornas handlande starkt kritiserats framför allt av de s.k. abolitionisterna. Enligt kritiken är de teorier som straffrätten bygger på ohållbara. ${ }^{7}$ En godtagbar grund för att upprätthålla straffsystemet saknas därigenom och det riktiga är därför att upplösa straffsystemet eller att åtminstone inskränka dess användningsområde. En sådan förstärkning av straffrättens roll som inrättandet av en internationell brottmålsdomstol (jämte uppsättandet av en internationell strafflag) skulle innebära går stick i stäv med dessa förslag. 
Det är min avsikt att i en tvådelad framställning kritiskt granska förslaget att inrätta en internationell brottmålsdomstol. Granskningen fokuseras inte på den domstol som FN:s säkerhetsråd har beslutat inrätta, utan på en permanent internationell brottmålsdomstol med en mer omfattande jurisdiktion. I den första delen kommer jag att redogöra för vissa av de centrala punkterna i M. Sherif Bassiounis förslag till grundstadga för den internationella brottmålsdomstolen. I en andra del försöker jag sedan göra en kriminalpolitisk bedömning av förslagets konsekvenser i det fall att det realiseras.

Den första delen kan således sägas vara en undersökning som gäller internationell straffrätt och straffprocessrätt, medan den andra delen kan hänföras till området för internationell kriminalpolitik.

\section{DEN INTERNATIONELLA BROTTMÅLSDOMSTOLEN (IBD)}

\subsection{Domstolens sammansättning}

I sitt förslag till grundstadga för den internationella brottmålsdomstolen (i fortsättningen kommer jag att använda mig av förkortningen IBD för att beteckna den internationella brottmålsdomstolen och förkortningen IBDG för Bassiounis förslag till dess grundstadga) utgår Bassiouni från att den skall ha fyra skilda organ: den egentliga domstolen ("rätten", "The Court"), ett åklagarämbete ("The Procuracy") ${ }^{8}$, ett sekretariat ("The Secratariat") och en bestående kommitté av medlemsstater ('The Standing-Committee of State-Parties"). ${ }^{9}$

Vid domstolen skall det finnas femton domare och tio domarsuppleanter ("alternate judges"). För bägge kategorierna gäller att aldrig mer än en får vara av samma nationalitet. Då den bestående kommittén väljer domare skall den därtill eftersträva att de personer som väljs har olika erfarenhet och bakgrund samt att världens alla stora rättssystem blir representerade inom domarkåren. ${ }^{10}$ Domarna skall vara högt kvalificerade för sin uppgift ("persons of the highest caliber of integrity and legal competence"). Det krävs särskilt att de är specialister på internationell straffrätt eller på internationella mänskliga rättigheter. ${ }^{11}$

Internationella brottmålsdomstolen skall enligt förslaget till grundstadga fungera i olika sammansättningar. Vid domstolen finns en särskild "rannsakningskammare" ('Indictment Chamber"). ${ }^{12}$ Den består av tre domare (som alternerar) och dess uppgift är att besluta om åtalet mot en anklagad person skall prövas eller ej ("issue the indictment"). Den egentliga huvudförhandlingen i ett brottmål sker vid en "beslutskammare" ("Adjudication Chamber") som också fattar det slutliga avgörandet och avkunnar domen. ${ }^{13}$ Också denna kammare har tre domare som utses för en sak i sänder, varvid de tre domare som tagit del i sakens behandling vid rannsakningskammaren är uteslutna.

Den tredje kammaren vid domstolen är en "appellationskammare" ("Appellate Chamber"). Vid den behandlas sådana ansökningar om ändring av av- 
göranden som rannsakningskammaren och beslutskammaren har fattat som målets parter har rätt att göra. Fråga är alltså om en "rättsmedelsinstans" inom domstolen. Appellationskammaren har fem domare som utses för en sak i sänder (varvid de domare som deltagit i saksbehandlingen vid rannsakningskammaren eller beslutskammaren är uteslutna). ${ }^{14}$

I vissa fall skall internationella brottmålsdomstolen fatta sina avgöranden i plenum med alla femton domare närvarande ('en banc'). Detta gäller t.ex. för beslut som innebär att ett slutligt avgörade av någon av domstolens kammrar "återbryts". 15

\subsection{Domstolens behörighet (jurisdiktion)}

Bassiounis förslag till grundstadga för den internationella brottmålsdomstolen utgår från att domstolens jurisdiktion begränsas till fyra fall: ${ }^{16}$

1) Fall 1. Domstolen avgör sådana tvister mellan medlemsstater som gäller tolkningen och tillämpningen av internationella brottmålskonventioner om vissa särskilt uppräknade internationella brott. ${ }^{17}$ Dessa tvister kan t.ex. gälla skyldigheten för viss stat att utlämna en person eller att inleda lagföring, staternas jurisdiktion över visst brott, frågor som gäller internationell rättshjälp i brottmål eller andra frågor som angår mellanstatligt samarbete i straffsaker.

2) Fall 2. Domstolen har en ursprunglig (primär) jurisdiktionsrätt över vissa särskilt uppräknade internationella brott. Denna jurisdiktionsrätt består i rätt (plikt) att inleda lagföring för ett sådant brott, pröva saken och utdöma straff. Lagföringen riktas i detta fall mot en sådan enskild fysisk person som är straffrättsligt ansvarig för brottet. De påföljder som utdöms kan emellertid också påföras juridiska personer (även stater). ${ }^{18}$

IBD:s jurisdiktion är i detta fall exklusiv i förhållande till medlemsstaternas domstolar. Bara IBD är behörig.

3) Fall 3. Domstolen har en jurisdiktion över vissa särskilt uppräknade internationella brott som konkurrerar med en sådan jurisdiktion som en nationell brottmålsdomstol i en medlemsstat har. Denna medlemsstat kan ge sitt implicita eller explicita samtycke till att IBD inleder och gemomför processen, eller alternativt, besluta att rättegången överförs från den nationella domstolen till IBD.

4) Fall 4. Domstolen har en ad hoc-jurisdiktion över vissa särskilt uppräknade internationella brott. Denna jurisdiktion grundar sig på en särskild begäran av en medlemstat om att IBD påtar sig ansvaret för rättegången för ett visst konkret brott.

Dessa fyra skilda fall av jurisdiktion kommer jag att benämna på följande sätt: behörighet (jurisdiktion) att avgöra tolkningstvister (fall 1), primär och exklusiv brottmålsjurisdiktion (fall 2), konkurrerande brottmålsjurisdiktion (fall 3) och ad hoc-brottmålsjurisdiktion (fall 4). 


\subsection{Förfarandet}

\subsubsection{Förberedelse}

En rättegång vid IBD kan enligt förslaget till grundstadga inledas på två olika sätt: ${ }^{19}$

I ett fall då domstolen har en primär och exklusiv jurisdiktionsrätt över brottet (fall 2 ovan), inleds rättegången på åklagarämbetets eget initiativ. Åklagarämbetet utför själv en förundersökning av brottet och besluter på basen av den att av rannsakningskammaren utverka ett beslut om att åtalet skall prövas vid beslutskammaren. ${ }^{20}$

Då IBD har en konkurrerande jurisdiktion (fall 3 ovan) eller en ad hoc-jurisdiktion (fall 4 ovan) över brottet förutsätter lagföringen vid domstolen alltid att en medlemstat framställt en begäran till IBD om att denna skall uppta saken till prövning. ${ }^{21}$ Denna begäran prövas först av åklagarämbetet. Om åklagarämbetet finner att begäran är uppenbart ogrundad ("manifestly unfounded") upptas saken inte till fortsatt prövning. ${ }^{22}$ Den medlemstat som har framställt begäran kan söka ändring i ett sådan negativt beslut av åklagarämbetet. Begäran om ändring prövas av IBD vid plenum med alla femton domare. ${ }^{23}$

Om åklagarämbetet inte finner att medlemsstatens begäran är uppenbart ogrundad genomför (slutför) ämbetet förundersökningen av brottet för att möjliggöra väckandet av åtal. En förutsättning för huvudförhandling vid beslutskammaren är också i detta fall att rannsakningskammaren besluter att åtalet skall prövas.

Förslaget till grundstadga för IBD innehåller flera bestämmelser som syftar till att göra förundersökningen effektiv. Åklagarämbetet föreslås få rätt att av beslutskammaren begära att vissa straffprocessuella tvångsmedel används under förundersökningen. Bland dessa tvångsmedel nämns uttryckligen beslut att anhålla (häkta) den misstänkte, beslut att en person instäms inför domstolen, beslut om interimistiska förordnanden eller förbud, beslut om husrannsakan och beslut att den anklagade skall överlämnas ("surrender") till domstolen för att svara på åtalet. ${ }^{24}$

Verkställigheten av dessa beslut förutsätter vanligen att en [medlems]stat ${ }^{25}$ ger IBD rättshjälp. Förslaget till grundstadga för IBD innehåller därför också ett omfattande kapitel om rättshjälp och andra former för samarbete. ${ }^{26}$

Enligt förslaget till grundstadga är en medlemsstat förpliktad att ge IBD all sådan rättshjälp som är internationellt erkänd. ${ }^{27}$ Denna rättshjälp skall primärt beviljas i enlighet med de bestämmelser som gäller i den stat som mottagit begäran om rättshjälp. ${ }^{28}$ För att några luckor inte skall uppstå i detta fall förutsätts det att envar medlemsstat vid behov kompletterar sin lagstiftning så att nödvändig rättshjälp alltid kan beviljas. ${ }^{29}$ Den nationella lagstiftningen får emellertid inte vara sådan att de minimigarantier som en brottsmisstänkt per- 
son har enligt de grundläggande internationella människorättsnormerna blir kränkta. ${ }^{30}$

Särskilt de bestämmelser som gäller sådan rättshjälp som innebär att en person överlämnas från en stat för att lagföras vid IBD är intressanta. ${ }^{31}$

Förslaget till grundstadga utgår från att en medlemsstat alltid då IBD framställer en begäran om att en person överlämnas till domstolen för lagföring ställs inför valet att bifalla denna begäran eller att själv inleda lagföring ("aut dedere, aut judicare"). I ett sådant fall då IBD har en primär och exklusiv jurisdiktionsrätt över brottet (fall 2 ovan) saknar emellertid den stat som mottagit IBD:s begäran någon annan möjlighet än att bifalla begäran. Den exklusiva domsrätten för IBD medför ju att staten själv saknar jurisdiktion över brottet. ${ }^{32}$

Förslaget till grundstadga för IBD utgår vidare från att alla de internationella brott som domstolen har jurisdiktion över ${ }^{33}$, är sådana att utlämning alltid är möjlig. ${ }^{34}$ För att några luckor inte skall uppstå i detta avseende förutsätts att envar medlemsstat kompletterar sin nationella utlämningslagstiftning och sina utlämningsavtal på ett sådant sätt att alla dessa brott $\mathrm{i}$ berörda bestämmelser erkänns som sådana brott som möjliggör utlämning. ${ }^{25}$

Enligt förslaget till grundstadga är en stats möjligheter att avslå en utlämningsbegäran av IBD mycket begränsade. Bara i två fall föreligger ett godtagbart utlämningshinder. Det första fallet gäller att brott som redan tidigare har avgjorts rättskraftigt (ne bis in idem), eller ett brott för vilket rätten att väcka åtal eller utdöma straff har preskriberats enligt lagen i den stat som mottagit utlämningsbegäran. I detta fall måste begäran avslås. ${ }^{36}$

I det andra fallet har den stat som mottagit begäran (fakultativ) rätt att avslå denna. Detta gäller för det fall att en brottmålsrättegång gällande samma brott och mot samma person som begäran avser redan är anhängig i denna stat. Möjligheten av avslå begäran saknes emellertid om begäran gäller ett brott för vilket IBD har primär och exklusiv jurisdiktion. ${ }^{37}$

Då det gäller två av de andra grunderna som traditionellt har utgjort utlämningshinder möjliggör förslaget till grundstadga ett "villkorligt överlämnande" ("Conditional Surrender"). Detta gäller för det första utlämning för ett brott som kan medföra dödsstraff. ${ }^{38}$ Den stat som mottagit begäran om utlämning kan härvid som villkor för överlämnandet av personen ställa att han/hon inte döms till döden. Det andra fallet då ett villkorligt överlämnande har gjorts möjlig är det fall att begäran gäller en person som är medborgare i den stat som mottagit begäran. Som villkor kan härvid uppställas att personen återförs till den utlämnande staten sedan lagföringen slutförts. Den utlämnande staten förbinder sig å sin sida att erkänna den dom som IBD avkunner i saken och att verkställa det straff som den utlämnade personen har döms till. ${ }^{39}$

Då åklagarämbetet har slutfört förundersökningen skall beslut om väckande 
av åtal fattas. Åklagarens beslut att väcka åtal skall därefter underkastas prövning vid rannsakningskammaren. Om rannsakningskammaren kommer till att saken är väl grundad både med avseende på relevanta rättsfakta och tillämplig lag ("reasonably founded in fact and law"), saken inte tidigare har blivit rättskraftig avgjord ("ne bis in idem") och inte några sådana omständigheter föreligger som skulle medföra att prövningen av saken skulle vara otillförlitlig eller orättvis ("unreliable or unfair") skall kammaren fatta ett beslut om att åtalet skall prövas vid beslutskammaren. ${ }^{40}$

\subsubsection{Huvudförhandling}

Förslaget till grundstadga för IBD utgår från att huvudförhandlingen är uppdelad i två faser. Under den första delen av huvudförhandlingen skall den åtalades skuld till brottet fastställas. Om den åtalade befinns vara skyldig fortsätter huvudförhandlingen med den andra delen, varvid domstolen bestämmer vilka straff och andra påföljder som skall utdömas.

Huvudförhandlingen sker inför beslutskammaren och den är offentlig, ifall säkerhetsskäl inte förutsätter att den förs bakom slutna dörrar. Den åtalade åtnjuter under förhandlingen sådana minimirättigheter som de internationella människorättsnormerna förutsätter. Vissa av dessa rättigheter regleras explicit i ett särskilt kapitel av IBDG. ${ }^{41}$

IBD är bunden av den straffrättsliga legalitetsprincipen. ${ }^{42}$ I förslaget till grundstadga anges principens innehåll genom fyra förbud: förbudet att stifta lagar som gäller gärningar som redan har begåtts ${ }^{43}$, förbudet att ge en lag retroaktiv verkan ${ }^{44}$, förbudet att anse en gärning för ett brott utan stöd i lag ${ }^{45}$ och förbudet att utdöma straff utan stöd i lag. ${ }^{46}$

Rättegången vid IBD skall genomföras ${ }^{47}$ så att bägge parter (åklagaren och den åtalade) år jämlika ("Equality of arms"). ${ }^{48}$ Den åtalade skall ha den fördel som följer av presumtionen som hans/hennes oskuld ("Presumption of Innocence"). Uttryckligen anges att bevisbörden skall ligga på åklagarsidan, att den åtalade inte är skyldig att bevisa sin oskuld, att den åtalade har rätt att förbli tyst under rättegången och att han/hon skall upplysas om denna rättighet, att en fällande dom alltid förutsätter att den åtalades skuld har fastställts "beyond a reasonable doubt" och att tveksamhet om den åtalades skuld alltid skall leda till hans/hennes frikännande. ${ }^{49}$

Vid förfarandet inför IBD făr enbart sådana bevis användas som tagits fram och som kan företaes utan kränkning av internationella mänskliga rättigheter. Förslaget till grundstadga innehåller ett uttryckligt förbud att som bevis använda information som har erhållits på ett sätt som inneburit en allvarlig kränkning av internationella människorättsnormer (". . . by illegal means which constitutes a gross violation of internationally protected human rights ...")..$^{50}$ 
Den första delen av huvudförhandlingen avslutas med en dom som gäller den åtalades skuld. Om domstolen funnit att den åtalades skuld fastställs så starkt att någon rimlig misstanke om hans/hennes oskuld inte längre föreligger, förklaras den åtalade skyldig, varefter den andra delen av huvudförhandlingen kan vidta. Under denna del av förfarandet skall sådan bevisning företas som är av betydelse för straffmätningen, d.v.s. bevisning om fakta som minskar eller ökar den åtalades skuld. ${ }^{51}$

\subsubsection{Rättsmedel}

IBD:s domar är slutliga, d.v.s. ändring i dem kan inte sökas vid någon annan nationell eller internationell domstol. På grund av att de internationella människorättsnormerna förutsätter att en person som dömts för brott skall ha rätt att få avgörandet omprövat vid en annan, högre domstol, föreslås i grundstadgan att internationella brottmålsdomstolen skall ha en särskild appellationskammare. Vissa avgöranden som rannsakningskammaren eller beslutskammaren har fattat kan omprövas vid denna "högre" kammare. ${ }^{52}$

Den mest omfattande rätten att söka ändring $i$ avgöranden av rannsakningskammaren och beslutskammaren har den åtalade. Åklagarens rätt att söka ändring är mer begränsad (bara avgöranden som gäller rättsfrågor).

Förslaget till grundstadga för IBD innehåller också en bestämmelse som möjliggör att domstolen genom ett beslut fattat i plenum upphäver en tidigare slutlig dom (d.v.s. en dom given av rannsakningskammaren eller beslutskammaren som inte överklagats, eller en dom av appellationskammaren). Fråga är om något som svarar mot det extraordinära rättsmedel som kallas resning (återbrytande av dom). Också grunderna för när en sådan resning är möjlig svarar i huvudsak mot dem som brukar godkännas i nationell rätt (bl.a. nya fakta som påverkar domslutet). ${ }^{53}$

\subsection{Verkställighet av straff och andra påföljder}

Förslaget till grundstadga för IBD förutsätter att de straff och andra påföljder som domstolen utdömer verkställs i någon medlemsstat. Då domstolen tillämpat en viss medlemsstats strafflag ${ }^{54}$, skall straffverkställigheten anförtros denna stat. Då IBD:s jurisdiktion varit primär och exklusiv och avgörandet därför har fattats med omedelbar stöd av internationella normer skall domstolen begära att straffet verkställs $\mathrm{i}$ en sådan medlemsstat som den finner vara lämplig. ${ }^{55}$ Straffverkställigheten sker alltså genom internationell rättshjälp mellan IBD och en medlemsstat.

Vid straffverkställigheten tillämpas de normer för verkställighet av straff som gäller i den stat där verkställigheten sker. ${ }^{56}$ IBD skall dock hela tiden övervaka straffverkställigheten. Detta sker genom att beslutskammaren alltid då den 
dömer en person till straff också utser en av den internationella brottmålsdomstolens domare att personligen övervaka straffverkställigheten ("Supervisor"). ${ }^{57}$

Denna "straffverkställighetsdomare" skall tillse att straffet verkställs på det sätt som IBD förutsatt i domen. Den dömde har emellertid rätt att av straffverkställighetsdomaren begära förändringar av straffet. Om denna anser att en sådan begäran är befogad skall han/hon hänskjuta frågan till beslutskammaren, som i förslaget till grundstadga föreslås få en viss rätt att ompröva straffet. ${ }^{58}$

\subsection{Tillämplig materiell lag (tillämpliga straffbud)}

Enligt förslaget till grundstadga för IBD är domstolens val av tillämplig materiell lag bundet till de olika fallen av jurisdiktion. ${ }^{59}$

I två fall skall domstolen tillämpa den nationella strafflagen i en medlemsstat. Detta är fallet då IBD:s behörighet konkurrerar med behörigheten för domstol i en medlemsstat (d.v.s. då domstolen har en konkurrerande brottmålsjurisdiktion [fall 3 ovan]). Härvid skall IBD antingen tillämpa strafflagen i den stat från vilken lagföringen överförts till IBD, eller (då lagföringen vid IBD inte sker efter överföring, utan med implicit eller explicit samtycke av sådan medlemsstat som har primär jurisdiktion över brottet) strafflagen i någon sådan medlemsstat vars jurisdiktion över brottet kan härledas med stöd av territorialitetsprincipen, eller med stöd av den passiva eller den aktiva personalitetsprincipen. ${ }^{60}$

Också då IBD har en ad hoc-jurisdiktion över det brott, som åtalet avser (d.v.s. det fall som ovan betecknats som fall 4) skall domstolen tillämpa den nationella strafflagen $\mathrm{i}$ en medlemsstat. Tillämplig strafflag är härvid den lag som IBD och den medlemsstat (eller de medlemsstater) som hänskjutit fallet till IBD kommer överens om. Det förutsätts emellertid i detta fall att lagvalet inte leder till en konflikt med folkrättsliga normer. ${ }^{61}$

I de två återstående fallen - d.v.s. då IBD avgör sådana tvister mellan medlemsstater som gäller tolkningen och tillämpningen av internationella brottmålskonventioner (fall 1), samt då IBD har en primär och exklusiv jurisdiktionsrätt (fall 2 ovan) - skall domstolen tillämpa sådana internationella normer som enligt art. 38 stadgan om internationella domstolen erkänns som källor inom folkrätten. ${ }^{62}$

Då IBD lagför ett internationellt brott som primärt behörig domstol (fall 2) är den dock alltid bunden av den straffrättsliga legalitetsprincipen. De materiella normer som den tillämpar på ett fall får alltså inte vara sådana som är förbjudna enligt legalitetsprincipen i den utformning som denna princip erkänns ha "in the world's major criminal justice systems". ${ }^{63}$

Förslaget till grundstadga för IBD innehåller inte någon explicit hänvisning till en internationell strafflag. Uppenbart är emellertid att förslaget bygger på tanken att en sådan strafflag skall antas och att detta helst skall ske samtidigt med att den internationella brottmålsdomstolen grundas. ${ }^{64}$ 
Däremot innehåller förslaget till grundstadga för IBD en särskild artikel som gäller påföljder och straff som domstolen kan utdöma (art. XXI). ${ }^{65}$ Följande straff nämns: frihetsberövande påföljd eller sådana kontrollåtgärder som innebär ett mindre ingrep i personens frihet än frihetsberövande ${ }^{66}$, samt böter och konfiskation av brottsprodukten ("proceeds of criminal conduct"). Som andra påföljder nämns förbud att delta i viss verksamhet eller viss form av aktivitet samt återställande och skadestånd. ${ }^{67}$

Denna förteckning över straff och påföljder som IBD kan döma till är inte uttömmande. Då domstolen blivit behörig på grund av att saken överförts till denna av en medlemsstat tillämpar domstolen ju strafflagen i denna stat (eller någon annan stats nationella strafflag). Domstolen kan härvid döma till alla de straff och påföljder som ingår i denna lag. IBD får emellertid inte döma till straff och påföljder som står i strid med internationell rätt. Om den omedelbara tillämpningen av en nationell strafflag skulle ha denna följd skall IBD modifiera straffen och påföljderna så att de står i överensstämmelse med "international norms and standards". 68

\section{DEN INTERNATIONELLA STRAFFLAGEN}

\subsection{Brott som omfattas av IBD:s jurisdiktion}

Bestämmelserna i förslaget till grundstadga för IBD om domstolens jurisdiktion utgår från att denna begränsas till vissa internationella eller transnationella brott. Domstolen skulle alltså inte vara behörig att lagföra rent nationella brott. Brottet måste vara en sådan gärning som kränker ett "överstatligt rättsgott" (alltså ett internationellt brott) eller en gärning med beröringspunkter till minst två stater (ett transnationellt brott). ${ }^{69}$

Förslaget till grundstadga utgår från att alla de brott som kan falla under IBD:s jurisdiktion uttömmande uppräknas i en sådan överenskommelse som en stat ingår med domstolen då den erkänner dess behörighet. Till förslaget till grundstadga finns fogat fyra bilagor ("Annex") som upptar förteckningar över de internationella (transnationella) brott som domstolens jurisdiktion i olika fall kan omfatta.

Den längsta förteckningen upptar de brott som är sådana att domstolen är behörig att avgöra eventuella tvister mellan medlemsstaterna som gäller straffrättslig domsmakt, internationell rättshjälp etc. (det fall som gäller domstolens behörighet att avgöra tolkningstvister). Denna förteckning är samtidigt en grundförteckning över de internationella brotten. ${ }^{70}$ Förteckningen är alltså uttömmande. Andra brott än de som uppräcknas i förteckningen kan inte vara sådana internationella brott som IBD kan få jurisdiktion över. Brotten i de andra förteckningarna utgör ett urval av vissa av de brott som ingår i grundförteckningen. ${ }^{71}$ 
I förslaget till grundstadga för IBD har den förteckning som upptar sådana brott som omfattas av domstolens primära jurisdiktionsrätt lämnats helt öppen. Här gäller det således för en stat som erkänner IBD och dess primära, exklusiva jurisdiktion över vissa internationella brott att ur grundförteckningen över internationella brott välja dem som den önskar anförtro IBD:s uteslutande domsmakt. De internationella brott som är sådana att både en nationell domstol och IBD kan ha jurisdiktion över dem (fallet med konkurrerande jurisdiktion) har däremot uppräknats $\mathrm{i}$ en särskild förteckning (eller mer exakt, ett förslag till förteckning - avgörande är det avtal som respektive medlemsstat ingår med IBD). ${ }^{72}$

\subsection{De internationella (transnationella) brotten}

Grundförteckningen över de internationella brotten upptar sammanlagt 24 brott. ${ }^{73}$ Dessa är:

1) Anfallskrig (Aggression)

2) Krigsbrott (War crimes)

3) Olovligt bruk, framställning och upplagring av vissa förbjudna vapen (Unlawful use, production and stockpiling of certain prohibited weapons)

4) Brott mot mänskligheten (Crimes against humanity)

5) Folkmord (Genocide)

6) Apartheid

7) Slaveri och slaverirelaterade gärningar (Slavery and slave-related practices)

8) Tortyr (Torture)

9) Olovliga människoexperiment (Unlawful human experimentation)

10) Sjöröveri (Piracy)

11) Brott mot den internationella sjöfarten (Offences against international maritime navigation)

12) Olovligt besittningstagande av luftfartyg, sabotage och med dessa relaterade brott (Unlawful seizure of aircraft, sabotage and related crimes)

13) Övergrepp mot personer som åtnjuter internationellt beskydd (Attacks against internationally protected persons)

14) Tagande av gisslan (Taking of hostages)

15) Olovligt bruk av post [för terrorhandlingar] (Unlawful use of the mails [for terror violence])

16) Narkotikabrott [internationella] (Drug offences [international])

17) Förstörande av och/eller stöld av nationella skatter och kulturellt arvegods (Destruction and/or theft of national treasures and cultural heritage)

18) Miljöbrott (Environmental offences)

19) Kapande av undervattenskablar (Cutting of submarine cables)

20) Internationell handel med osedliga produkter (International traffic in obscene materials)

21) Förfalskning [av mynt] (Counterfeiting [currency]) 
22) Bestickning av främmande stats ämbetsman (Bribery of foreign public officials)

23) Stöld av nuklära produkter (Theft of nuclear materials)

24) Legoknektskap (Mercenarism)

Förteckningen över de internationella brotten innehåller inte någon närmare beskrivning av brotten. Det förutsätts därför att brottens gärningsbeskrivningar tillräckligt tydligt och klart (d.v.s. på ett sådant sätt som legalitetsprincipen förutsätter) framgår ur någon annan rättskälla. Vilka dess rättskällor är beror på vilket fall av jurisdiktion som ger IBD behörighet. ${ }^{74}$ Rättskällan kan vara en nationell strafflag (vid konkurrerande jurisdiktion eller ad hoc-jurisdiktion) eller (vid primär, exklusiv jurisdiktion) en sådan rättskälla som folkrätten allmänt godkänner, alltså först och främst en folkrättslig konvention.

Uppenbart är emellertid att förslaget att grunda en internationell domstol är sammankopplat med ett förslag om att "stifta" en internationell strafflag. De 24 brott som ingår i förteckningen ovan svarar nämligen mot de brott som ingår i den särskilda delen i ett förslag till internationell strafflag som Bassiouni lagt fram i en bok, senast år $1987 .{ }^{75}$ Bassiounis förhoppning är att detta förslag skall godkännas av FN för att sedan i form av ett folkrättsligt traktat bli en primär folkrättslig rättskälla. ${ }^{76}$

En granskning av de 24 brotten som föreslås utgöra de internationella brotten visar att alla de "klassiska" internationella brotten - alltså de brott som redan åtalspunkterna vid rättegångarna i Nürnberg och Tokyo efter andra världskriget - ingår bland dessa. ${ }^{77}$

En granskning av de föreslagna gärningsbeskrivningarna för brotten visar att bland dem också ingår alla andra sådana brott som redan nu kan anses vara "internationella brott omedelbart med stöd av folkrätten" ("folkrättsbrott') d.v.s. slaveri och slaverirelaterade gärningar (slavhandel och gärningar som påminner om slaveri [livegenskap, tvångsprostitution och tungt tvångsarbete], folkmord, tagande av gisslan, tortyr och andra grymma och brutala former av behandling och bestraffning, grov diskriminering av viss människogrupp eller människokategori, användande av stränga kollektiva straff samt godtyckligt dödande och summariska rättegånger. ${ }^{78}$

Flera av de föreslagna brotten är sådana som kan betecknas som "världsbrott", d.v.s. sådana gärningar som i en internationell konvention förutsätts vara straffbelagda och därtill på ett sådant sätt att en lagföring och bestraffning inte förutsätter att kravet på dubbel straffbarhet är uppfyllt. ${ }^{79}$ Klara exempel på detta är följande brott i den ovan citerade förteckningen: apartheid ${ }^{80}$, tortyr ${ }^{81}$, sjöröveri ${ }^{82}$, brott mot den internationella sjöfarten ${ }^{83}$, olovligt besittningstagande av luftfartyg, sabotage och med dessa relaterade brott ${ }^{84}$, övergrepp mot personer som åtnjuter internationellt beskydd ${ }^{85}$, tagande av gisslan ${ }^{86}$, narkotikabrott ${ }^{87}$ och stöld av nukleära produkter. ${ }^{88}$ 
Vissa av brotten i den föreslagna förteckningen över internationella brott är emellertid sådana som (i nuvarande rättsläge) varken är folkrättsbrott eller världsbrott. I dessa fall innebär ett godkännande av förslaget således att nya internationella brott skapas. De mest uppenbara exemplen på detta är brotten förstörande av och/eller stöld av nationella skatter och kulturellt arvegods (brott 17), miljöbrott (brott 18) och bestickning av främmande stats ämbetsman (brott 22). ${ }^{88}$

Åtminstone ett av brotten, nämligen internationell handel med osedliga produkter (brott 20) är åter sådant att dess egenskap som internationellt brott visserligen kan härledes från en internationell konvention, men trots detta kan behovet av att ge det status som centralt internationellt brott starkt ifrågasättas. ${ }^{90}$ Den förhärskande rättsuppfattningen (i Norden) är knappast den att en gärning som består i "framställning, tillverkning, innehav, transport, import, export eller distribution av osedliga produkter för annat än för eget personligt bruk mellan två eller flera stater" utgör ett så allvarligt brott mot mänskligheten att det är nödvändigt att ge en internationell brottmålsdomstol behörighet att lagföra det. ${ }^{91}$

\section{EN RÄTTSLIG BEDÖMNING AV ETABLERINGEN AV IBD OCH ANTAGANDET AV EN INTERNATIONELL STRAFFLAG}

Komprimerat kan den ordning som föreslås bli realiserad genom inrättandet av en internationell brottmålsdomstol beskrivs på följande sätt: ${ }^{92}$

a) För lagföringen och bestraffningen av vissa internationella brott har IBD en primär och exklusiv behörighet. Dessa brott bestraffas med stöd i de allmänt erkända folkrättsliga rättskällorna, d.v.s. folkrättslig sedvana (folkrättsbrotten), folkrättsliga traktat (de nuvarande världsbrotten) och/eller den internationella strafflag som antas bli antagen (de framtida internationella brotten). De straff och andra påföljder som domstolen kan utdöma anges härvid av art XXI i IBDG.

Vilka brott som är sådana att IBD har denna primära och exklusiva behörighet beror på de överenskommelser som IBD:s medlemsstater gör med domstolen. Innebörden av en sådan överenskommelse är att en medlemsstat avstår från sin egen straffrättsliga jurisdiktion ifråga om vissa brott och överlåter den på IBD.

b) För lagföringen och bestraffningen av vissa internationella brott har IBD en konkurrerande behörighet. I dessa fall har alltid också en viss [medlems]stat jurisdiktion över brottet. Lagföringen kan överföras från en sådan stat till IBD genom ett beslut fattat i denna stat. Lagföringen vid IBD kan emellertid också inledas genom en begäran av någon annan stat, varvid det förutsätts att den stat som har den konkurrerande jurisdiktionen ger sitt explicita eller implicita sam- 
tycke till lagföringen. IBD:s avgöranden grundas i detta fall på straffbestämmelserna i någon nationell strafflag (den stats strafflag varifrån lagföringen överförts eller strafflagen i en sådan stat som har jurisdiktion över brottet med stöd av territorialitetsprincipen). Också straffen och de andra straffrättsliga påföljderna bestäms av denna nationella strafflag.

c) För lagföringen och bestraffningen av ett visst internationellt brott har IBD en ad hoc-behörighet på grund av att en stat som har jurisdiktion över brottet har begärt att IBD skall överta lagföringen och bestraffningen. IBD fattar sina avgöranden med stöd av den nationella strafflagen i någon stat. Vilken stats strafflag som väljs beror på ett avtal mellan IBD och den stat som framställt begäran.

Det presenterade förslaget till grundstadga för en internationell brottmålsdomstol innehåller flera "eleganta" lösningar på sådana problem som tidigare har visat sig vara centrala tvistefrågor. Realiserat skulle förslaget utan tvekan betecknas som ett viktigt steg i utvecklingen av den internationella straffrätten och straffprocessrätten.

Denna bedömning får sitt berättigande av att alla tidigare försök att etablera en permanent internationell brottmålsdomstol har misslyckats. ${ }^{93}$ De brottmålsdomstolar som grundades efter andra världskriget (i Nürnberg och Tokyo) för rättegångarna mot de krigsansvariga var inte permanenta. Det har också ifrågasatts om dessa domstolar egentligen var internationella. ${ }^{94}$ De internationella domstolar som redan nu finns saknar åter behörighet att pröva och utdöma straff för (straffrättsliga) brott: de kan alltså inte betecknas som brottmålsdomstolar. ${ }^{95}$

En av de viktigaste stötestenarna vid de tidigare försöken att grunda en internationell brottmålsdomstol har varit frånvaron av en sådan internationell strafflag som domstolen kunde tillämpa i sin verksamhet. Man har menat att om det inte finns en sådan internationell strafflag som innehåller de gärningsbeskrivningar som konstituerar de internationella brotten och straffen för dessa brott, saknar en internationell brottmålsdomstol verksamhetsmöjligheter. Också frågan om hur straff och andra påföljder som den internationella domstolen dömer ut skall verkställas har ansetts vara ett stort problem, då en internationell ordning för detta saknas.

Det aktuella förslaget innehåller lösningar på bägge dessa problem. I två av de tre fall då IBD har en egentlig jurisdiktion över brott, d.v.s. i de fall som avser en konkurrerande brottmålsjurisdiktion respektive en ad hoc-brottmålsjurisdiktion, tillämpar domstolen en nationell strafflag. I bägge dessa fall förutsätts att den gärning som lagföringen gäller utgör ett brott enligt den nationella lag som IBD tillämpar och att denna lag är gällande i en stat som primärt har jurisdiktion över brottet. Fråga är således om fall då en viss stat avstår från att 
använda den subjektiva rätt att bestraffa ett brott ('jus puniendi") som den har med stöd av sin egen strafflagstiftning och överlåter utövningen av denna rätt åt IBD. ${ }^{96}$

Man har antagit att denna möjlighet att överföra lagföringen av ett internationellt brott från en stat som har jurisdiktion över brottet till IBD kunde användas framför allt $\mathrm{i}$ sådana fall då lagföringen vid en nationell domstol inte kan genomföras utan betydande säkerhetsrisker. Som exempel kan nämnas lagföringen av internationella narkotikabrott i sådana stater där denna typ av brottslighet kontrolleras av mäktiga brottssyndikat (t.ex. vissa av de sydamerikanska staterna). En rättegång vid en internationell brottmålsdomstol antas härvid vara ett säkrare alternativ.

I ett fall tillämpar IBD folkrättsliga normer vid lagföringen av brott. Detta gäller det fall då domstolens jurisdiktion är primär och exklusiv. Också i detta fall är emellertid envar medlemsstats rätt att bestämma vilka materiella normer som skall bli tillämpade stor. Förslaget till grundstadga förutsätter ju att envar medlemsstat explicit avtalar med IBD om vilka internationella brott (av dem som ingår i grundförteckningen) som domstolens primära jurisdiktion skall omfatta. Varje stat kan härvid välja dessa brott så att den redan på förhand kan överblicka de folkrättsliga normer som blir tillämpliga. På några få undantag när framgår gärningsbeskrivningarna för ifrågakommande internationella brott redan nu ur gällande internationella brottskonventioner. ${ }^{97}$

Problemet med verkställigheten av straff och andra straffrättsliga påföljder kan åter med säkerhet ordnas på det föreslagna sättet, genom internationell rättshjälp.

Samtidigt är det helt uppenbart att de föreslagna lösningarna också skapar vissa nya problem. Den föreslagna ordningen med en överstatlig domstol (IBD) och nationella domstolar i kombination med de föreslagna bestämmelserna om lagval kan leda till olika "nya" rättskonflikter. Jag skall försöka beskriva vissa sådana konfliktsituationer med hjälp av följande scheman.

I det första schemat beskrivs de olika alternativ som finns med avseende på en viss gärning som utgör/kan utgöra ett internationellt brott enligt a) strafflagen i en viss stat respektive b) de internationella normer som IBD tillämpar då dess behörighet är primär och exklusiv.

Schema 1. Gärningen kriminaliserad.

I staten S:s strafflag

ja

nej

ja

nej
I de folkrättsliga rättskällorna

ja
nej
nej
ja


Schemat anger att en viss gärning är kriminaliserad som ett brott både enligt staten S:s strafflag och enligt de folkrättsliga normerna (fall 1), inte enligt någondera (fall 2), enligt staten S:s strafflag men inte enligt de folkrättsliga normerna (fall 3), eller enligt de folkrättsliga normerna men inte enligt staten S:s strafflag (fall 4).

Av de fyra fallen är det den konfliktsituation som uppstår i fall 4 som är problematisk. ${ }^{98}$ I detta fall utgör en gärning inte ett brott enligt strafflagen i staten S. Någon möjlighet att inleda lagföring för och bestraffa brottet finns alltså inte i denna stat - inte ens i det fall att gärningen har förövats inom dess territorium. ${ }^{99}$

Men om staten S i en överenskommelse med IBD har tillerkänt domstolen en primär och exklusiv jurisdiktion över ett sådant internationellt brott som gärningen konstituerar, har IBD möjlighet att genom sina egna organ inleda lagföring för gärningen och bestraffa den med stöd av de internationella normer som den härvid tillämpar. Detta gäller också för det fall att gärningspersonen är medborgare i staten $\mathrm{S}$ och brottet har begåtts i denna stat. Något krav på "dubbel straffbarhet" uppställs således inte. ${ }^{100} \mathrm{I}$ detta fall föreligger alltså en situation då en person kan bli dömd till straff för en sådan gärning som han/hon har begått i sin egen hemstat och som inte enligt lagen i denna stat är straffbar. ${ }^{101}$

Konfliktsituationerna blir flera och mer komplicerade då två eller flera stater är involverade. Följande schema får illustrera detta.

I strafflagen i

S1 S2

ja nej

nej nej

ja ja

nej ja

Schema 2. Gärningen kriminaliserad.

Schemat anger olika alternativ för en viss gärnings straffbarhet enligt strafflagen i två skilda stater (S1 och S2) samt enligt de folkrättsliga normerna (för fullständighetens skull anges också i detta fall två skilda alternativ [alt. 1 respektive alt. 2]). ${ }^{102}$

Olika typer av positiva/negativa rättskonflikter uppstår i alla de fall då de tre rättskällorna inte är identiska. De märkligaste konflikterna uppkommer i en situation då IBD med olika typ av kompetens (samtidigt) behandlar (samma typ av) brott begångna av två eller flera personer från olika stater:

Två personer (A respektive $\mathrm{B})$ från två skilda stater (S1 respektive S2) begår samma typ av gärning i var sitt hemland. Denna gärningen är kriminaliserad i A:s hemstat S1, men inte i B:s hemstat S2. Enligt de internationella normerna konstituerar gärningen emellertid också att internationellt brott, och staten S2 har i en överens- 
kommelse med IBD erkänt domstolens primära jurisdiktion över detta brott. Detta har staten S1 inte gjort, men denna stat har åter med IBD överenskommit om att detta brott är sådant att IBD har en konkurrerande jurisdiktion.

Ifall staten $\mathrm{S} 1$ nu bestämmer sig för att överföra lagföringen för A:s brott till IBD och IBD självmant inleder lagföringen för B:s brott, kommer den att tillämpa två skilda uppsättningar av normer på samma (typ av) gärning (d.v.s. bestämmelserna $\mathrm{i}$ S1:s strafflag på A:s brott och de folkrättsliga normerna på B:s brott).

Detta är knappast problematiskt så länge som de straff och andra påföljder som enligt respektive rättskällor kan utdömas för brottet är ungefär lika stränga. Men så snart skillnaden mellan de möjliga straffen blir stora uppstår problem. Särskilt tillspetsad blir situationen om straffet för brottet enligt lagen i S1 är dödsstraff. Kan IBD $\mathrm{i}$ ett sådant fall döma A till döden (med stöd av lagen i S1), men underlåta att göra det i B:s fall då de internationella normer som den tillämpar i hans fall inte anvisar dödsstraff som en möjlighet? ${ }^{103}$

Förslaget till grundstadga för IBD innehåller också andra väl motiverade lösningar på gamla tvistefrågor inom den internationella straffrätten och straffprocessrätten än dem som berörts ovan. Det kan särskilt nämnas att grundstadgan entydigt tagit ställning för att också enskilda fysiska personer kan vara folkrättsliga subjekt med ett straffrättsligt ansvar som primärt grundas på folkrättsliga normer. Det kan vidare noteras att grundstadgan mycket klart och "progressivt" har angett det skydd som en anklagad person skall åtnjuta med stöd av internationella mänskliga rättigheter. För en jurist van vid den kontinentala processrättens betoning av rättegångens syfte att finna "den materiella sanningen" framstår t.ex. förbjudet att som bevis utnyttja sådant material som åtkommits genom en allvarlig kränkning av människorättsnormer mer kategoriskt än vanligt.

Att det aktuella förslaget om att etablera en internationell brottmålsdomstol i flera avseenden är juridiskt "elegant" behöver emellertid inte betyda att den föreslagna lösningen också är rättspolitiskt lyckad. Förslaget kan ha sådana verkningar som inte kan accepteras då de bedöms med stöd av de humana nordiska värderingar som varit förhärskande inom de senaste decenniernas kriminalpolitik.

\section{Noter}

1) Konferensens arrangörer var bl.a. Association Internationale de Droit Pénal (AIDP), International Centre for the Reform of Criminal Law, International Scientific and Professional Advisory Council of the United Nations Crime Prevention and Criminal Justice Programme och Parliamentarians for Global Action.

2) Bassiouni, M. Cherif: Draft Statute International Criminal Tribunal. Nouvelles études pénales. érès 1992 .

Också invitationen till konferensen var undertecknad av Bassiouni, som för tillfället bl.a. verkar som ordförande för AIDP.

3) Bassiounis förslag till grundstadga för en internationell brottmålsdomstol är inte det enda aktuella förslaget. International Law Commission har på uppdrag av FN:s 
generalförsamling (resolution 46/54, januari 1992) behandlat frågan om etableringen av en internationell brottmålsdomstol. Det förslag som ILC utarbetat är inte lika detaljerat som Bassiounis. ILC:s bedömning av möjligheterna att grunda en sådan domstol är också betydligt mindre entusiastiska än Bassiounis. Se international Law Commission. Fortyfourth session, Geneva 4 May-24 July 1992. Draft Code of Crimes against the Peace and Security of Mankind. Report of the Working Group on the question of an international criminal jurisdiktion.

4) Bassiouni beskriver dessa försök $\mathrm{i}$ sin publikation med förslag till grundstadga för den internationella brottmålsdomstolen ("Chronology of Efforts to Establish an International Criminal Court'). Se Bassiouni 1992, s. 29-45.

Grundandet av en internationell brottmålsdomstol berörs i två viktiga internationella instrument. Konventionen om förebyggande och bestraffning av folkmord (New York 1948) tillerkänner en internationell brottmålsdomstol jurisdiktion över brottet folkmord under förutsättning av att en sådan domstol inrättas (art. 6). Konventionen förutsätter således inte uttryckligen att en internationell brottmålsdomstol grundas. Detta är däremot fallet ifråga om den internationella konventionen om undertryckande och bestraffning av brottet apartheid (New York 1973). Art. 5 i denna konvention förutsätter att en "international criminal jurisdiktion" etableras. Detta har inte skett. Se Bassiouni 1992, s. 7-10.

5) Bassiouni bedömer att attityden till en internationell brottmålsdomstol nu har ändrats $i$ en positiv riktning. Som stöd anför han att frågan behandlats $i$ "positiv anda" vid FN:s generalförsamling 1989 och vid FN:s specialsession kring narkotika 1990 sedan 15 länder från Karibien och Syd-Amerika understött idén. Han konstaterar också att bl.a. president Gorbachov understött tanken på en internationell brottmålsdomstol. Se Bassiouni 1992, s. 11 och s. 14-15.

6) Erfarenheterna efter det första världskriget visar just sådana svårigheter. Efter krigsslutet fattade de allierade ett beslut om att ställa tyska kejsaren, vissa ledande politiker och vissa militära ledare till straffrättsligt ansvar vid en international tribunal för krigshandlingarna. Detta beslut kunde aldrig realiseras på grund av att de ansvariga inte utlämnades för lagföringen från hemstaten/vistelsestaten. Se Jung, Susanne: Die Rechtsprobleme der Nürnberger Prozesse dargestellt am Verfahren gegen Friederick Flick. Tübingen 1992, s. 92-93.

7) En översiktlig och aktuell kritisk granskning av dessa teorier finns i Mathiesen, Thomas: Kan fängelset försvaras? Göteborg 1988.

8) En chefsåklagare ("Procurator-General") förestår och leder åklagarämbedet. Vid ämbetet finns därtill andra åklagare samt brottsutredare och nödvändig kanslipersonal. Chefsåklagaren väljs för sex år i taget genom beslut av den bestående kommittén. Se förslag till grundstadga för den internationella brottmålsdomstolen (IBDG) art. XVI.

9) Den bestående kommittén har flera uppgifter. Bland uppgifterna är valet av domare och domarsuppleanter ("alternate judges") och valet av chefsåklagare de vigtigaste. Den bestående kommittén skall också vid behov förlika konflikter mellan medlemsstater som hänför sig till domstolens uppgifter och verksamhet. Se IBDG art. XVIII:2.

10) Domarna väljs alltid för en viss termin: fem domare väljs för en termin på fyra år, fem för en termin på sex år och fem för en termin på åtta år. Domare och domarsuppleanter kan inte omväljas för mer än två efterföljande mandatperioder. Se IBDG art. XV:4.

11) Se IBDG art. XV:2. Det föreslås inte att sysslan som domare vid IBD skall vara ett heltidsvärv, men domarens möjligheter att sköta andra yrken och uppgifter föreslås vara begränsade. En domare vid IBD kan samtidigt vara domare vid en domstol $\mathrm{i}$ den stat varifrån han blivit vald eller medlem av en universitetsfakultet. Andra yrken, uppgifter och funktioner är inte tillåtna. Se IBDG art. XV:5-6.

12) Art. XV:17 och art. XXIV.

13) Art. XV:17 och art. XXVI. 
14) Art. XV:17 och art. XXVIII.

15) Se om denna möjlighet IBDG art. XXVIII:6.

16) Se IBDG art. XIX.

17) Dessa brott uppräknas i bilagor till IBDG ("Annex 1, Annex 2, Annex 3"). Se närmare avsnitt 3 nedan.

18) Se BDG art. XXI.

19) Då IBD avgör en tvist mellan två medlemsstater (fall 1 ovan) är det inte i egentlig mening frågan om en brottmålsrättegång mot en anklagad person utan om en form av folkrättsligt skiljeförfarande. Detta förfarande behandlar jag inte närmare.

20) IBDG art. XXIV:1.

21) IBDG art. XXIV:1. Förslaget till grundstadga förefaller inte att vara helt klart på denna punkt. Enligt art. XIX:3 har IBD en konkurrerande jurisdiktion över brottet (fall 3 ovan) också då en medlemsstat med primär jurisdiktion ger sitt implicita samtycke till att processen genomförs vid IBD (". . . on the basis of . . . implicit consent by a State-Party . . ."). Denna bestämmelse förefaller öppna en möjlighet för IBD att på eget initiativ inleda en process också i fall 2 utan en uttrycklig begäran av en medlemsstat, men med denna stats tysta samtycke. Art. XXIV:1 förutsätter dock alltid $\mathrm{i}$ ett sådant fall att medlemsstat med jurisdiktion över brottet begär lagföring vid IBD.

22) IBDG art. XXIV:2.

23) IBDG art. XXIV:3.

24) IBDG art. XXV:2 ("Arrest-Warrents", "Subpoenas", "Injunctions", "Search-Warrants", "Warrants for surrender of an accused so as to enable accused persons to be brought before the Court").

25) IBDG begränsar inte rättshjälpen till hjälp mellan IGD och en medlemsstat, utan utgår från att också icke-medlemsstater i vissa fall samtycker till att bevilja rättshjälp. Se IBDG art. XXXV:1(b) och art. XXXVI.

26) Kapitel 8. "Judicial Assistance and Other Forms of Cooperation".

27) IBDG art. XXXV:2. Följande former av rättshjälp nämns särskilt: utlämning för brott, delgivning av kallelser, stämningar och andra motsvarande rättshandlingar, rättshjälp för att säkerställa bevisning, överlämnande av nödvändiga personhandlingar (inklusive utdrag ur straffregister), information om gällande rätt, överföring av lagföring, överföring av dömd person och erkännande av brottmålsdom som IBD har avkunnat.

Grundstadgan förutsätter också att vissa provisoriska tvångsmedel (tillfälligt omhändertagande av misstänkt person, tillfälligt beslag av dokument och föremål etc.) skall kunna användas genom rättshjälp. Se också IBDG art. XXXVII:6 och art. XLI.

28) IBDG art. XXXVII: 1 .

29) IBDG art. XXXV:3.

30) IBDG art. XLIV.

31) Tre former for rättshjälp har i praktiken denna innebörd: utlämning för brott ("Extradition"), överlämmande ("Surrender") och överföring av person ("Transfer of person"). Särskilt när det gäller de två första begreppen förefaller förslaget till grundstadga för IBD inte att göra någon väsentlig skillnad mellan åtgärderna.

32) IBDG art. XXXVIII.

33) Se närmare avsnitt 3 nedan.

34) IBDG art. XL:1(a).

35) IBDG art. XL:1(b).

36) IBDG art. XL:4(a).

37) IBDG art. XL:4(b).

38) IBDG art. XL:3(a). Konsekvenserna av denna bestämmelse behandlar jag närmare i framställningens kriminalpolitiska del!

39) IBDG art. XL:3(b). Det är skäl att notera att denna bestämmelse också i vissa andra avseende förefaller vara betydligt restriktivare än motsvarande utlämningsbestämmelser i nordisk lagstiftning vanligen är idag. 
Bestämmelsen förutsätter för det första att hindret att utlämna en egen statsmedborgare framgår ur statens grundlag ('In the event that the national constitution of a State-Party . . ."). För det andra nämns i bestämmelsen enbart statens egna medborgare (" ... its nationals ..."). Om detta tolkas strikt ordagrant kan bestämmelsen inte utsträckas till att omfatta också personer som är fast bosatta i staten, eller medborgare $\mathrm{i}$ andra närliggande stater. De nordiska staterna har ju under de senaste decennierna haft en mycket generös inställning till vem som jämställs med egna statsmedborgare då det gäller förbud att utlämna. Vid tolkningen och tillämpningen av den europeiska utlämningskonventionen har alla nordiska länder deklarerat att med "nationals" också avses personer som är fast bosatta i staten och person som är medborgare i eller fast bosatt i en annan nordisk stat.

40) IBDG art. XXV:1.

41) Chapter 5. Procedures and Rules of the Fairness of the Tribunal.

42) IBDG art. XXII:2.

43) "Prohibition of ex post facto laws".

44) "Non-retroactivity of criminal laws and penal sanctions".

45) "Nullum criminen sine lege".

46) "Nulla poena sine lege".

Det kan noteras att grundstadgan inte explicit berör den aspekt av legalitetsprincipen som gäller kravet på straffbudens tydlighet och klarhet. Jfr Frände, Dan: Den straffrättsliga legalitetsprincipen. Ekenäs 1989, s. 4.

47) Förslaget till grundstadga förutsätter att förfarandet skall slutföras så snabbt som möjligt ('Speedy Trial"). IBDG art. XXII:4.

48) Se IBDG art. XXVI:4. Den åtalade skall alltid ha rätt att anlita ett juridiskt biträde. IBDG art. XXII:7.

49) Se IBDG art. XXII:3 och XXII:6.

50) IBDG art. XXII:5.

51) IBDG art. XXVII.

52) Se IBDG art. XXVIII ("Appeals").

53) IBDG art. XXVIII:6.

54) Se närmare nedan avsnitt 2.5.

55) Den medlemsstat som IBD vänder sig till med begäran om att verkställa straffet föreslås få viss rätt att avslå begäran. Enligt förslaget till grundstadga har medlemsstaten en sådan rätt då den saknar möjligheter att sköta verkställigheten, då den dömda personen inte är medborgare i medlemsstaten eller fast bosatt i denna, då den dömda personen fortfarande är så ung att verkställigheten av ett sådant straff som han/hon har dömts till inte är möjlig enligt lagen i denna stat eller då det straff som IBD har utdömt är av en sådan art, typ eller längd som står i strid med vad som allmänt accepteras i medlemsstaten. Se IBDG art. XLIII:2.

56) IBDG art. XXIX:1 och XLIII:1. Också möjligheten att villkorligt frige en dömd person skall avgöras enligt lagen i den stat som verkställer straffet. Beträffande verkställighet av bötesstraff och konfiskation föreslås att lagen i den stat som verkställer straffet skall tillämpas, men de pengar som indrivs skall tillfalla IBD. Se art. XLIII:6.

57) IBDG art. XXIX:2.

58) IBDG art. XXIX:3.

59) Se avsnitt 2.2 ovan.

60) IBDG art. XX:4. Förslaget til grundstadga anger inte närmare vad som i detta sammanhang skall anses vara innebörden av dessa principer. Detta kan lätt leda till svårigheter då bestämmelsen tolkas och tillämpas. Skall t.ex. en stat anses ha jurisdiktion över ett brott med stöd av den aktiva personalitetsprincipen också då brottet har begåtts av en person som är fast bosatt i denna stat eller gäller detta enbart för fall då gärningspersonen är medborgare $\mathrm{i}$ staten. I de nordiska länderna är man t.ex. beredd att utvidga jurisdiktionen med stöd av den aktiva personalitetsprincipen till brott som begåtts av medborgare i den egna staten, personer som är 
tast bosatta i denna stat och personer som är medborgare eller fast bosatta $\mathrm{i}$ en annan nordisk stat, men vistas i domstolsstaten. Se Nord 1992:17. Straffrättslig jurisdiktion i Norden. Andra staters tolkning av vad som avses med den aktiva personalitetsprincipen kan vara betydlig mer restriktiv.

61) IBDG art. XX:5.

62) Dessa källor uppdelas i artikeln i två huvudgrupper. De primära rättskällorna är internationella överenskommelser (folkrättsliga traktat), internationell sedvana och allmänna rättsprinciper som erkänts av de civiliserade folken. De subsidiära rättskällorna är rättsliga avgöranden och de olika ländernas mest sakkunniga forskares lärosatser.

63) Se IBDG art. XX:3. Det är självklart att de sekundära folkrättskällorna vanligen inte har den kvalitet som den straffrättsliga legalitetsprincipen förutsätter för att de skulle kunna fungera som självständiga källor. Av de primära rättskällorna är både den internationella sedvanan och de allmänna rättsprinciper som de civiliserade folken erkänner problematiska bedömda utgående från legalitetsprincipens krav. Den huvudsakliga rättskällan för IBD måste därför, åtminstone då det gäller att avgöra vilka gärningar som utgör internationella brott, vara folkrättsliga överenskommelser. Se Frände, s. 8-9.

Frågan om vilka begränsningar legalitetsprincipen ställer för bestraffning av en viss gärning hörde till de centrala under Nürnbergrättegångarna. Som en sammanfattning av de synpunkter som härvid fördes fram kan man konstatera att "nulla poena sine lege"-kravet ansågs vara uppfyllt om det var klart att ifrågavarande gärning vid gärningstidpunkten var folkrättsligt "rättsstridig" (rechtswidrig). Då man avgjorde detta kunde man stöda sig på internationella traktat samt på allmänt erkänd sedvana samt på allmänna rättsgrundsatser. Se Jung, särskilt s. 164 (. . . "aus Vertragen, Gebräuchen und Gewohnheiten, die allmählich allgemeine Ànerkennung gefunden hätten, und aus Rechtsgrundsätzen, die der allgemeinen Rechtsüberzeugung entsprächen").

64) Se avsnitt 3 nedan.

65) Att grundstadgan innehåller bestämmelser om vilka straff som IBD kan utdöma har en enkel förklaring: i de fall då domstolen inte tillämpar en nationell strafflag utan en folkrättslig norm, anger inte det tillämpliga "straffbudet" någon bestämmelse om vilket straff som skall utdömas för gärningen. Gärningens straffbarhet bedöms ju huvudsakligen utgående från någon internationell brottmålskonvention och dessa innehåller inte några explicita bestämmelser om vilket straff som skall följa på den gärning, vars kriminalisering konventionen förutsätter. Bestämmelserna om de straff som IBD kan utdöma har intagits $\mathrm{i}$ förslaget till grundstadga för att fylla detta vakuum. Bestämmelserna blir tillämpliga bara då IBD har en primär och exklusiv jurisdiktion.

66) Förslaget till grundstadga för IBD anger inte något maximum för frihetsstraffet. Den enda begränsningen $\mathrm{i}$ detta avseende är uppenbarligen den att det utdömda straffet skall "conform to international norms and standards".

67) IBDG art. XXI:1.

68) IBDG art. XXI:3. Se närmare om detta i avsnitt 3 nedan.

69) Jag kommer inte $\mathrm{i}$ fortsättningen att göra någon skillnad mellan ett internationellt brott och ett transnationellt brott. Då jag använder begreppet "internationellt brott" omfattar detta således bägge grupperna.

70) Annex 1. "Proposed Schedule of Crimes which the State-Parties recognize as susceptible of being the subject of the Tribunal's jurisdiktion in accordance with Article XIX."

71) Då en (eller flera) medlemsstater begär att IBD sköter lagföringen av ett konkret brott (fallet som ger IBD en ad hoc-jurisdiktion) kan detta brott vara vilket som helst av dem som upptas på grundföreteckningen över internationella brott.

72) Annex 3. "Proposed Schedule of Crimes contained in Annex 1 for which the Tribunal would have Jurisdiction based on Concurrent and/or Transfer of Criminal Proceedings in accordance with Article XIX, paragraph 3." 
73) Alltså "Annex 1".

74) Se ovan avsnitt 2.5.

75) Bassiouni, M. Cherif: A Draft International Criminal Code and Draft Statute for an international Criminal Tribunal. Dordrecht, Boston, Lancaster 1987. (Rev. ed. of "International criminal Law. 1980).

76) Också International Law Commission utarbetar på uppdrag av FN ett förslag till internationell strafflag ("Draft Code of Crimes Against the Security of Mankind"). Se Bassiouni 1992, s. 19. Det är i alla fall uppenbart att inte detta förslag utan Bassiounis eget förslag utgör den modell för en internationell strafflag som Bassiouni har sammankopplat med sitt aktuella förslag om att inrätta en internationell brottmållsdomstol. Bassiounis bok A Draft International Criminal Code and Draft Statute for an International Criminal Tribunal från år 1987 innehåller förutom förslaget till en internationell strafflag en tidigare version av förslaget till en grundstadga för en internationell brottmålsdomstol. Det förslag som jag analyserar i denna framställning är alltså en reviderad version av detta tidigere utkast.

77) Åtalspunkterna gällde tre kategorier av brott: brott mot freden, krigsförbrytelser och brott mot humaniteten. Se Träskman, P. O.: En granskning av den finska straffrättens tillämpningsområde. Borgå 1977, s. 24-25.

78) Se Hannikainen, Lauri: Peremtory Norms (Jus Cogens) in International Law. Historical Development, Criteria, present Status. Helsinki 1988, s. 425-595.

79) Se Nord 1992:17, s. 117-119. Se beträffande begreppet "världsbrott" Träskman, P. O.: Internationell straffrätt och utomnationell straffrätt. Försök till en gränsdragning. JFT 1977, s. 397.

80) Se International Convention on the Suppression and Punishment of the Crime of Apartheid (1973).

81) Convention against torture and other cruel, inhuman or degrading treatment or punishment (1984).

82) Convention on the high seas (1958) och Convention on the Law of the Sea (1982).

83) Convention for the suppression of unlawful acts against the safety of maritime navigation (1988).

84) Convention for the suppression of unlawful seizure of aircraft (1970) och Convention for the suppression of unlawful acts against the safety of civil aviation (1971).

85) Convention on the prevention and punishment of crimes against internationally protected persons, including diplomatic agents (1973).

86) International convention against taking of hostages (1979).

87) Convention against illicit traffic in narcotic drugs and psychotropic substances (1988).

88) Convention on the physical protection of nuclear material (1980). Också vissa av de brott som ovan har betecknats som "folkrättsbrott" regleras i dag av en internationell konvention. Detta gäller för krigsbrotten, brott mot mänskligheten och folkmord. Se även Nord 1992:17, s. 118-119.

89) Då det gäller de två förstnämnda brotten finns det visserligen i bakgrunden sådana internationella konventioner som fördömer de gärningar som föreslås bli kriminaliserade. Gärningsbeskrivningen för förstörande av och/eller stöld av nationella skatter och kulturellt arvegods bygger framför allt på UNESCO konventionen om olagligt flyttande av konstskatter (Convention on the Illicit Movement of Art Treasures) från år 1970. I denna konvention finns det emellertid inte någon bestämmelse som skulle förplikta en medlemsstat att kriminalisera den gärning som nu föreslås bli ett internationellt brott. Se Bassiouni 1987, 167-169. Bestämmelser som förutsätter kriminalisering ingår däremot $\mathrm{i}$ den Europakonvention om brott med avseende på egendom med kulturellt värde som antogs 23.6.1985.

Beträffande den föreslagna kriminaliseringen av miljöbrott kan åter konstateras att mycket få av de internationella konventioner som gäller miljöskydd förutsätter en uttrycklig kriminalisering av en viss beskriven gärning. Den gärningsbeskrivning som brottet föreslås få är också så omfattande att fullt stöd för kriminaliseringen 
inte går att finna i de existerande miljökonventionerna. Se också Träskman, P. O.: Miljöbrott och kontroll av miljöbrottslighet. Helsingfors 1992, s. 127-128.

Beträffande den föreslagna gärningsbeskrivningen för brottet bestickning av främmande stats ämbetsmän konstaterar Bassiouni: Though not yet recognized as an international crime, the consensus of the world community warrants its inclusion in this Draft Code. Bassiouni 1987, s. 177.

90) Flera internationella konventioner förutsätter att spridning av pornografi kriminaliseras. Den vigtigaste av dessa är den internationella konventionen, som avser underundertryckande av spridningen av och handeln med osedliga publikationer (sluten $\mathrm{i}$ Genève 1923). Se också Bassiouni 1987, s. 165.

91) Av de nordiska länderna är visserligen åtminstone Finland fortfarande bunden av pornografikonventionen av år 1923 .

92) Ur denna sammanfattande beskrivning utelämnar jag det fall av jurisdiktion som ger IBD behörighet att lösa tvister gällande bestraffning av och internationell rättshjälp för lagföring av interationella brott.

93) Det är fortfarande oklart hur den internationella krigsförbrytardomstol som FN:s säkerhetsråd beslutat inrätta skall klassificeras. Allt tyder dock på att den skall ha funktionen av en "tillfällig" domstol, inrättad bara för krigsbrott (brott mot humaniteten som begåtts $\mathrm{i}$ de pågående kriget inom det forna Jugoslavien. Fråga är alltså inte om en permanent internationell brottmålsdomstol.

94) Se Jung, s. 109-136. Domstolarna har också betecknats som de allierade besättningsmakternas domstolar, eller bara som organ för "Siegerjustiz".

95) Den Internationella domstolen i Haag avgör framför allt sådana tvister mellan domstolens medlemsstater som underställs denna. Dessa tvister kan gälla olika frågor $\mathrm{i}$ anslutning till tolkningen av internationella fördrag, andra internationellrättsliga spörsmål såsom åsidosättandet av internationella förpliktelser. Domstolen kan också bestämma om gottgörelse för konstaterat åsidosättande av förpliktelse.

Europadomstolens (Luxemburg) kompetens är åter begränsad till tolkning och tillämpning av de europeiska gemenskapernas egna normer. Trots att EG framför allt inom konkurrensrättens område kan påföra sådana verksamheter som brutit mot EG-normerna stora böter, betecknas dessa inte i rättslig bemärkelse som straffrättsliga sanktioner. Europadomstolen kan därför inte heller betecknas som en brottmålsdomstol. Se även Greve, Vagn: Strafferet og politisamarbejde. Juristen nr. 5/1992, s. 234-237. Inte heller Internationella människorättsdomstolen (Strasbourg) kan betecknas som en internationell brottmålsdomstol. Domstolens kompetens begränsas till att avgöra om någon medlemsstat har brutit mot den europeiska människorättskonventionen och dess tillägsprotokoll.

96) Man kan tillspetsat säga att IBD i dessa fall bara används som en handske för att utföra det "smutsiga jobb" som en viss stat inte själv vill utföra.

97) Jfr ovan avsnitt 3.2 .

98) Fallen 1 och 2 innehåller ingen konflikt. Konflikten i fall 3 löser sig själv. På grund av att gärningen inte utgör ett brott enligt sådana folkrättsliga rättskällor som IBD skall tillämpa $\mathrm{i}$ ett fall då dess behörighet är primär, kan ett åtal för gärningen inte aktualiseras i detta jurisdiktionsfall (som är det enda då IBD omedelbart tillämpar internationella normer). I de andra fallen (konkurrerande jurisdiktion och ad hocjurisdiktion) tillämpar IBD en nationell strafflag och som en sådan lag kan då också lagen i staten $\mathrm{S}$ användas.

99) Jag frånser från en sådan (sällsynt) undantagssituation då domstolen $\mathrm{i}$ en stat $\mathrm{i}$ ett brottmål tillämpar strafflagen i en annan stat. Se Jescheck, Hans-Heinrich: Gegenstand und neueste Entwicklung des Internationalen Strafrechts. Festschrift für Reinhart Maurach zum 70. Geburtstag. Herausgegeben von Friedrich-Christian Schroeder und Heinz Zipf. Karlsruhe 1972, s. 579-580.

100) Orsaken till detta är uppenbarligen att man utgått från att de folkrättsliga normerna eo ipse har en universell giltighet och att problemet med "dubbel strafbarhet" därför är helt irrelevant. Hittills har detta antagande inte varit korrekt då man van- 
ligen inte har erkänt möjligheten för en nationell domstol att som omedelbar rättskälla i ett brottmål använda folkrättsliga normer.

101) Det är självklart att denna konfliktsituation bara uppkommer ifall den nationella strafflagen $i$ en viss stat är mer begränsad än de internationella normer som staten i sin överenskommelse med IBD har accepterat som materiellt tillämpliga i de fall då domstolen har en primär jurisdiktionsrätt. Att oönskade konfliktsituationer av detta slag kan uppstå följer bl.a. av att de folkrättsliga normerna ofta är svåra att tolka. IBD:s avgörande kan avvika från den tolkning som den egna statens domstolar och andra myndigheter har gjort.

102) Gärningen kan alltså vara kriminaliserad enligt normerna i alla tre källor (S1 ja, S2 ja och FR ja [alt. 2 rad 3]), vara okriminaliserad i alla (S1 nej, S2 nej och FR nej [alt. $1 \mathrm{rad}$ 2]), kriminaliserad i S1 och enligt de folkrättsliga normerna, men inte i S2 (S1 ja, S2 nej, FR ja [alt. 1 rad 1]) osv.

103) Också den "motsatta" situationen, d.v.s. den att det straff som är utsatt för gärningen i strafflagen i S1 är mycket lindrigt leder till en konflikt. Den möjlighet som förslaget till grundstadga ger för IBD att modifiera straffen $i$ en nationell strafflag som den tillämpar så att de "comply with international norms and standards" (IBDG art. XXI:3) kan inte ge domstolen rätt att höja på straffskalorna. Detta skulle strida mot legalitetsprincipen. 